\title{
Cesium Recovery Using Savannah River Laboratory Resorcinol-Formaldehyde Ion Exchange Resin
}
L. A. Bray
R. J. Elovich
K. J. Carson

March 1990

Prepared for the U.S. Department of Energy under Contract DE-AC06-76RLO 1830

Pacific Northwest Laboratory Operated for the U.S. Department of Energy by Battelle Memorial Institute 


\title{
DISCLAIMER
}

This report was prepared as an account of work sponsored by an agency of the United States Government. Neither the United States Government nor any agency thereof, nor Battelle Memorial Institute, nor any of their employees, makes any warranty, expressed or implied, or assumes any legal Ihability or responsibility for the accuracy, completeness, or usetulness of any information, apparatus, product, or process dlsclosed, or represents that its use would not infringe privately owned rights. Reference herein to any specific commercial product, process, or service by trade name, trademark, manufacturer, or otherwise, does not necessarily constitute or imply its endorsement, recommendation, or favoring by the United States Government of any agency thereof, or Battelle Memorial Institute. The views and opinions of authors expressed herein do not necessarily state or reflect those of the United States Government or any agency thereof.

\author{
PACIFIC NORTHWEST LABORATORY \\ operated by \\ BATTELLE MEMORIAL INSTITUTE \\ for the \\ UNITED STATES DEPARTMENT OF ENERGY \\ under Contract DE-ACO6-76RLO 1830
}

Printed in the United States of America

Available to DOE and DOE contractors from the

Office of Scientific and Technical Information, P.O. Box 62, Oak Ridge, TN 37831;

prices available from (615) 576-8401. FTS 626-8401.

Available to the public from the National Technical Information Service,

U.S. Department of Commerce, 5285 Port Royal Rd., Springfield, VA 22161.

NTIS Price Codes, Microfiche A01

Printed Copy

\begin{tabular}{cc}
\hline Price Code & Page Range \\
\hline A02 & $1-10$ \\
A03 & $11-50$ \\
A04 & $51-75$ \\
A05 & $76-100$ \\
A06 & $101-125$ \\
A07 & $126-150$ \\
A08 & $151-175$ \\
A09 & $176-200$ \\
A10 & $201-225$ \\
A11 & $226-250$ \\
A12 & $251-275$ \\
A13 & $276-300$ \\
A14 & $301-325$
\end{tabular}

\begin{tabular}{cc}
\hline Price Code & Page Range \\
\hline A15 & $326-350$ \\
A16 & $351-375$ \\
A17 & $376-400$ \\
A18 & $401-425$ \\
A19 & $426-450$ \\
A20 & $451-475$ \\
A21 & $476-500$ \\
A22 & $501-525$ \\
A23 & $526-550$ \\
A24 & $551-575$ \\
A25 & $576-600$ \\
A99 & $601-$ Up
\end{tabular}


PNL -7273

UC -510

\section{5}

\section{CESIUM RECOVERY USING SAVANNAH RIVER LABORATORY RESORC INOL - FORMALDEHYDE ION EXCHANGE RESIN}
L. A. Bray
R. J. Elovich
K. J. Carson

March 1990

Prepared for

the U.S. Department of Energy

under Contract DE-AC06-76RLO 1830

Pacific Northwest Laboratory

Richland, Washington 99352 



\section{SUMMARY}

A new ion exchange resin has been developed by the Savannah River Laboratory (SRL) for the recovery of radioactive ${ }^{137} \mathrm{Cs}$ from alkaline wastes produced by reprocessing fuels from nuclear reactors. The SRL resin is a condensation polymer made from resorcinol and formaldehyde. It has been shown to be stable to chemical and radiation attack in the highly concentrated and caustic supernatant waste. Sma11-scale testing was completed with excellent results (Bibler and Wallace 1987). The Pacific Northwest Laboratory ( $P N L)$ was requested to initiate a test program designed to provide additional experimental data needed to support further consideration of the resorcinol-formaldehyde ion exchange treatment for the Savannah River Site (SRS) alkaline waste.

Based on the results of the PNL study, the resorcinol-formaldehyde ion exchange resin was outstanding and performed better than any other know exchanger. The average ion exchange column loading was 220 column volumes (cv) of synthetic SRS waste at $50 \%$ cesium breakthrough, or 0.05 moles CS/L exchanger. A cesium decontamination factor (DF) of $>10^{4}$ was found for the treated SRS a Tkaline waste. A loss in cesium capacity of approximately 5 to $20 \%$ was observed after completion of seven loading/elution cycles. Approximately $99 \%$ of the cesium was eluted from the ion exchange resin in less than $10 \mathrm{cv}$ of $1 \mathrm{M}$ formic acid. Cesium elution product decontamination factors for sodium and potassium were $\sim 1400$ and $\sim 2400$, respectively. A detailed analysis of the results will be performed by SRL and only a general review will be included in this document. 
- 


\section{CONTENTS}

SUMMARY i i i

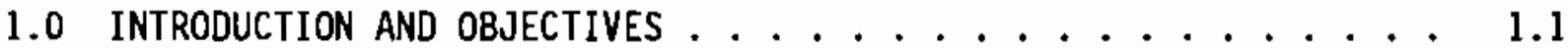

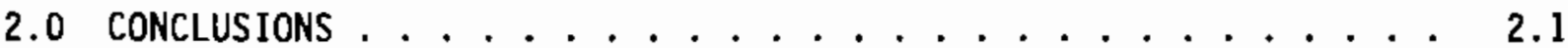

3.0 EQUIPMENT AND EXPERIMENTAL DESIGN ............... 3.1

3.1 PHASE 1--CAROUSEL CONFIGURATION . . . . . . . . . . 3.1

3.2 PHASE 2--SINGLE-COLUMN CONFIGURATION . . . . . . . 3.2

3.3 DESCRIPTION OF EQUIPMENT . . . . . . . . . . . . 3.2

3.4 SIMULATED SRS ALKALINE WASTE . . . . . . . . . . . 3.3

3.5 SAMPLE ANALYSIS . . . . . . . . . . . . . . 3.3

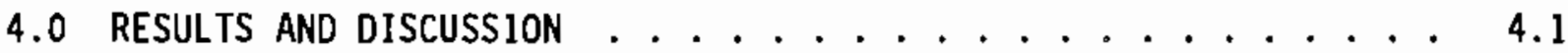

4.1 CAROUSEL CONFIGURATION . . . . . . . . . . . . . 4.1

4.2 CESIUM ELUTIDN USING FORMIC ACID . . . . . . . . . 4.2

4.3 SINGLE-COLUMN CONFIGURATION . . . . . . . . . . 4.5

4.4 PHYSICAL PROPERTIES .................... 4.6

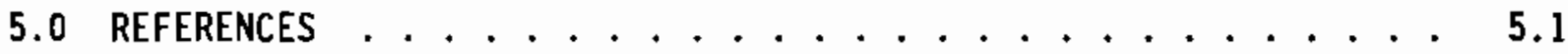




\section{FIGURES}

4.1 Cesium Breakthrough Profile for SRS Alkaline Waste Using BSC-187 Ion Exchange Resin ............. 4.3

4.2 Cesium Elution Profile of BSC-187 Ion Exchange Resin Using Formic Acid 4.4

\section{$\underline{\text { TABLES }}$}

3.1 SRS Simulated Supernatant . . . . . . . . . . . . . 3.3

4.1 Cesium Breakthrough Values as a Function of Feed Volume, Phase 1--Carousel Configuration . . . . . . . . . . . . 4.2

4.2 Decontamination Factors During Loading/Elution . . . . . . . 4.5

4.3 Cesium Breakthrough Values as a Function of Feed Volume, Phase 2--Single-Column Configuration . . . . . . . . . 4.6

4.4 Expansion and Contraction of Columns During Cycles . . . . . . 4.7 


\subsection{INTRODUCTION AND DBJECTIVES}

A new ion exchange resin has been developed by the Savannah River Laboratory (SRL) for the recovery of radioactive ${ }^{137}$ Cs from alkaline wastes that were produced by reprocessing fuels from nuclear reactors. The SRL resin is a condensation polymer made from resorcinol and formaldehyde. It has been shown to be stable to chemical and radiation attack in the highly concentrated and caustic supernatant waste. Smal1-scale testing (2 mL) at SRL has been completed with excellent results (Bibler and Wallace 1987). Boulder Scientific Co. (BSC), Boulder, Colorado then prepared kilogram quantities of the resin (BSC-1B7) for SRL. To establish the chemical longevity of the resin, the Pacific Northwest Laboratory (PNL) was requested to complete multiple feed/elution cycies using ${ }^{137} C_{5}$-spiked synthetic alkaline waste and multiple ion exchange columns.

This study was confined to the experimental measurements associated with the loading and formic acid elution of multiple $200-\mathrm{mL}$ ion exchange columns. The apparatus for these tests had previously been used to develop a multiple zeolite (IONSIV IE-96) ion exchange column system for the West Valley Nuclear Services Co., Inc. In that case, the performance observed with the laboratory columns was demonstrated to be equivalent to that observed in 4-ft-diameter by 10-ft-tall columns (Bray et al. 1989). 


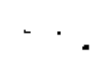




\subsection{CONCLUSIONS}

At the request of the Savannah River Operations Office of the U.S. Department of Energy (DOE) and the SRL, PNL has evaluated a new cesiumselective resorcinol-formaldehyde (CSRF) ion exchange resin. This resin was developed by SRL for the recovery of cesium from alkaline wastes now being stored at the Savannah River Site (SRS). Based on the resuits of this study, the CSRF ion exchange resin is expected to perform better than any other known ion exchange resin. This major conclusion is based on the following observations:

- The CSRF ion exchange resin performed with excellent results during six loading/elution cycles completed in the "carousel configuration." Each of the three ion exchange columns was loaded and eluted twice, and no loss of capacity of the resin was observed. The average cesium loading was $220 \mathrm{cv}$ at $50 \%$ cesium breakthrough, or 0.05 moles $C S / L$ exchanger.

- No detectable cesium was observed exiting the second and third columns in series when the first column had been loaded to $>0.5 \mathrm{C} / \mathrm{C}_{0}\left(\mathrm{C} / \mathrm{C}_{0}\right.$ is the ratio of effluent cesium concentration to that in the original feed). When the first column reached a 0.5 $\mathrm{C} / \mathrm{C}_{0}$ breakthrough, the effluent from the second and third columns had a cesium decontamination factor (DF) of $>10^{4}$. In addition, no loss of cesium DF was found when the first loaded/eluted column was placed in the third position during the subsequent loading cycle.

- A loss in cesium capacity of approximately 5 to $20 \%$ was observed after completion of seven CSRF loading/elution cycles.

- Approximately $99 \%$ of the cesium was eluted from the CSRF ion exchange resin in less than $10 \mathrm{cv}$ of $1 M$ formic acid, at flow rates that were varied from 0.5 to $2 \mathrm{cv} / \mathrm{h}$.

- Analyses of the feed and the formic acid elution product after CSRF ion exchange show a DF for cesium from sodium of 1400, and for cesium from potassium of 2400 .

- The 14.25-in.-tall test column containing $200 \mathrm{~mL}$ of CSRF ion exchange resin expanded by 1.5 in. during loading and shrank by 5 in. during elution. In addition, the resin pulled away from the column wall during formic acid elution. 


\subsection{EQUIPMENT AND EXPERIMENTAL DESIGN}

The laboratory work was divided into two phases. Both Phase 1 and Phase

2 consisted of the operation of a system for removing cesium, containing ${ }^{137} \mathrm{Cs}$ tracer, from simulated SRS alkaline salt solution.

\subsection{PHASE 1--CAROUSEL_CONFIGURATION}

The system consisted of three ion exchange columns ( $A, B$, and $C$ ) arranged in carousel configuration and designed so that they could be sequenced in the following manner during the completion of six cesium loading/elution tests:

\begin{tabular}{cc} 
Test \# & Column Sequence \\
\cline { 1 - 1 } 1 & A, B, C \\
2 & B, C, A \\
3 & C, A, B \\
4 & A, B, C \\
5 & B, C, A \\
6 & C, A, B
\end{tabular}

The tests were conducted as follows:

1) Three columns (200 mL of BSC-187, 30 to 60 mesh) were arranged in series and loaded downflow at a flow rate of $2 \mathrm{cv} / \mathrm{h}$, which is comparable to that expected at the SRS.

2) Each of the three columns was filled with $72 \mathrm{~g}$ of as-received BSC187 pretreated with $2 M$ sodium hydroxide $(\mathrm{NaOH})$. The columns were connected in series and the excess $2 \mathrm{M} \mathrm{NaOH}$ above each exchange bed was removed through the bottom sampling valve. Feed was started through the first column and the liquid heads above each column were re-established.

3) When the first column was loaded to $-50 \%$ cesium breakthrough $\left[{ }^{137} \mathrm{Cs}\right.$ effluent count rate $(C) \div{ }^{3} \mathrm{Cs}$ feed count rate $(\mathrm{Co})=0.5 \mathrm{j}$ at approximately $250 \mathrm{cv}$, feed flow was interrupted and the system was washed downflow first with $3 \mathrm{cv}$ of $2 \mathrm{M} \mathrm{NaOH}$ solution and then with $6 \mathrm{cv}$ of water $(2 \mathrm{cv} / \mathrm{h})$. All three columns were then in an interstitial water condition. The $\mathrm{NaOH}$ wash was used to remove residual sodium aluminate from the system prior to water washing, so that aluminum precipitation would be avoided. 
4) The first loaded and washed column was then detached and eluted downflow with 5 to $15 \mathrm{cv}$ of 1 formic acid at flow rates varying from 0.5 to $2 \mathrm{cv} / \mathrm{h}$ and rinsed with $3 \mathrm{cv}$ of water at $2 \mathrm{cv} / \mathrm{h}$. The first column was then reattached in the third position. The previous second column in the series then became the first, and the previous third column became the second.

5) Before loading again for the next cycle, $3 \mathrm{cv}$ of $2 \mathrm{M} \mathrm{NaOH}$ wash $(2 \mathrm{cv} / \mathrm{h}$ ) was fed to the new first column to prevent the feed from contacting water (to prevent aluminum precipitation).

6) Samples of the feed, midfluent between the first and second columns, midfluent between the second and third columns, and the effluent were $\$ 9 l$ lected at regular intervals $(-4$ to $16 \mathrm{~h}$ during loading) for ${ }^{137} \mathrm{Cs}$ radiochemical analysis to establish breakthrough values $\left(\mathrm{C} / \mathrm{C}_{0}\right)$ and $\mathrm{DFs}$.

7) The temperature of the water-jacketed ion exchange columns was maintained at $35^{\circ} \mathrm{C}$ using a temperature-controlled water bath.

\subsection{PHASE 2--SINGLE-COLUMN CONFIGURATION}

The objective of Phase 1 was to repeat the feed/elution cycle six times to establish the longevity of the resin. At the end of these cycles, each of the three columns had been loaded and eluted twice. No decrease in capacity had been observed. To obtain additional data, Phase 2 was initiated using only column $C$, which was loaded and eluted an additional five times using the same conditions outlined for Phase 1 .

\subsection{DESCRIPTION OF EOUIPMENI}

The experimental apparatus consisted primarily of three columns, a feed bottle, and a weighing effluent bottle. Each column had a capacity of $200 \mathrm{~mL}$ of ion exchange material and was 1 in. in diameter and 16.5 in. tall (including head space for solution above the resin bed). They were equipped with water jackets connected to a temperature bath so that a constant temperature was maintained. The columns were connected so that they were fed downflow from a $15-L$ feed tank. A feed pump located just upstream of the first column was used to control the flow rate. A valve was located at the bottom of each column from which each column's effluent was sampled. The effluent from the last column in series was routed to the weighing bottle. The column volumes 
of the effluent processed were determined by the effluent weight and specific gravity of the feed. A $24,600 \pm 0.1-\mathrm{g}$ balance was used to determine the weight of the effluent.

\subsection{SIMULATED SRS ALKALINE WASTE}

Simulated SRS alkaline supernatant was prepared according to Table 3.1 and traced with ${ }^{137} \mathrm{Cs}$.

\subsection{SAMPLE ANALYSIS}

A standard sample ( $4 \mathrm{~mL}$ ) of the feed (Co) was compared with the effluent (C) obtained during ion exchange processing of the SRS feed. Gamma counting was used for the determination of ${ }^{137} C_{S}$ and was performed in the laboratory using a multichannel analyzer and NaI well detector. Samples of effluent from the bottom of each column were taken every 4 to $16 \mathrm{~h}$. This was accomplished by opening the valve at the bottom of each column and collecting $\sim 5 \mathrm{ml}$. of column effluent in a plastic beaker. Exactly $4 \mathrm{~mL}$ of the effluent was then transferred to a test tube for counting. The test tubes and corks were numbered and the counting results logged onto data sheets, along with the results of the sample counting.

\section{TABLE 3.1. SRS Simulated Supernatant}

\begin{tabular}{lccc}
\multicolumn{1}{c}{ Component } & Concentration, mole/L & Concentration, g/L \\
\cline { 1 - 1 } $\mathrm{NaOH}$ & 2.90 & 116.0 \\
$\mathrm{Al}\left(\mathrm{NO}_{3}\right)_{3} \cdot 9 \mathrm{H}_{2} \mathrm{O}$ & 0.38 & 142.6 \\
$\mathrm{NaNO}_{3}$ & 1.19 & 101.2 \\
$\mathrm{NaNO}_{2}$ & 0.71 & 49.0 \\
$\mathrm{Na}_{2} \mathrm{CO}_{3} \cdot \mathrm{H}_{2} \mathrm{O}$ & 0.20 & 24.8 \\
$\mathrm{Na}_{2} \mathrm{SO}_{4}$ & 0.17 & 24.2 \\
$\mathrm{KNO}_{3}$ & 0.015 & 1.52 \\
$\mathrm{CSNO}_{3}$ & 0.00025 & 0.049
\end{tabular}





\subsection{RESULTS AND DISCUSSION}

A test program was designed to provide the experimental data needed to support further consideration of CSRF ion exchange treatment of SRS alkaline wastes. A detailed analysis of the results will be performed by SRL, and only a general review will be included in this document. This program was completed in two phases: 1) carousel configuration, and 2) single-column configuration. Results of these tests are given below.

\subsection{CAROUSEL CONFIGURATION}

The CSRF ion exchange resin performed with excellent results during six loading/elution cycles completed in the "carousel configuration." Each of the three ion exchange columns was loaded and eluted twice. No loss of cesium capacity of the resin was observed after the completion of this work. The average cesium loading was $220 \mathrm{cv}$ at $0.5 \mathrm{c} / \mathrm{C}_{0}$, or a cesium loading capacity of 0.05 moles $C S / L$ exchanger.

The results of the first and second loading/elution cycles (SRL \#1 and \#2) were not typical of those of the remaining tests. The reason for the initial poor loading performance (SRL \#1) has not been identified. The resin had been presoaked in $2 \mathrm{M} \mathrm{NaOH}$ and was loaded into Column $\mathrm{A}$. One possible cause for the poor loading performance was inadequate packing of the initial resin in the loading column resulting in solution channeling. However, tests SRL \#3 through \#6 showed very sharp cesium breakthrough performance. No detectable cesium was observed exiting the second and third columns in series (SRL \#2 through \#6) when the first column had been loaded to $>0.5 \mathrm{C} / \mathrm{C}_{0}$. When the first column reached a $0.5 \mathrm{C} / \mathrm{C}_{0}$ breakthrough, the effluent from the second and third columns had a cesium decontamination factor of $>10^{4}$. In addition, no loss of CS DF was found when the first loaded/eluted column was placed in the third position during the subsequent loading cycle. The cesium breakthrough values are shown in Table 4.1 and in Figure 4.1 as a function of the cumulative number of column volumes of feed passed through the column during the six loading/elution cycles. The column volumes of feed that passed through the loading column before a cesium value of $0.5 \mathrm{C} / \mathrm{C}_{0}$ was obtained during each cycle varied from 195 to 239 , with an 
TABLE 4.1. Cesium Breakthrough Values as a Function of Feed Volume, Phase 1--Carousel Configuration

\begin{tabular}{|c|c|c|c|c|c|c|c|c|c|c|c|}
\hline \multicolumn{2}{|c|}{ 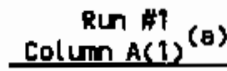 } & \multicolumn{2}{|c|}{$\begin{array}{r}\text { Rum B2 } \\
\text { Colum } B(1) \\
\end{array}$} & \multicolumn{2}{|c|}{$\begin{array}{c}\operatorname{Run} \text { 极 } \\
\text { Collum } c(1) \\
\end{array}$} & \multicolumn{2}{|c|}{$\begin{array}{c}\text { Run } \\
\text { Colum } A(2) \\
\end{array}$} & \multicolumn{2}{|c|}{$\begin{array}{c}\text { Run } \$ 5 \\
\text { Colum } B(2) \\
\end{array}$} & \multicolumn{2}{|c|}{$\begin{array}{c}\text { Run } \# \\
\text { column } c(2) \\
\end{array}$} \\
\hline$\overline{c v}$ & $C / c_{D}$ & $\mathrm{cr}$ & $C / c_{0}$ & $\mathrm{cr}$ & $c / c_{0}$ & $\overline{c V}$ & $c / c_{0}$ & $c r$ & $c / c_{0}$ & $c v$ & $\mathrm{c} / \mathrm{c}_{0}$ \\
\hline 6 & 0.0016 & 3 & 0.02 & 52 & $<0.0005$ & 177 & 0.0002 & 15 & 0.0002 & 135 & 0.0001 \\
\hline 41 & 0.018 & 63 & 0.02 & 106 & $<0.0005$ & 195 & 0.006 & 218 & 0.05 & 207 & 0.006 \\
\hline 48 & 0.056 & 96 & 0.04 & 158 & 0.0005 & 203 & 0.03 & 226 & 0.15 & 216 & 0.065 \\
\hline 70 & 0.10 & 104 & 0.05 & 187 & 0.31 & 207 & 0.07 & 233 & 0.30 & 220 & 0.11 \\
\hline 101 & 0.19 & 125 & 0.10 & 195 & 0.50 & 210 & 0.10 & 237 & 0.47 & 228 & 0.26 \\
\hline 129 & 0.29 & 141 & 0.16 & & & 220 & 0.23 & 238 & 0.50 & 232 & 0.39 \\
\hline 161 & 0.36 & 160 & 0.27 & & & 225 & 0.34 & & & 239 & 0.50 \\
\hline 170 & 0.40 & 172 & 0.34 & & & 231 & 0.50 & & & & \\
\hline 217 & 0.41 & 188 & 0.43 & & & & & & & & \\
\hline & & 218 & 0.50 & & & & & & & & \\
\hline & & उ7 & 0.67 & & & & & & & & \\
\hline
\end{tabular}

(a) $($ ) = number of times colum was used as the loading colum.

average value of $220 \mathrm{cv}$. Therefore, the capacity of the resin can be estimated as 220 times the cesium feed concentration $(0.00025 \underline{\mathrm{M}} \mathrm{Cs})$ or 0.05 moles CS/L exchanger.

\subsection{CESIUM ELUTION USING FORMIC ACID}

After cesium had been loaded onto the first column to $\sim 0.50 \mathrm{C} / \mathrm{C}_{0}$ breakthrough, the system was prepared for cesium elution from the first of three columns by flushing the three-column system with $\mathrm{NaOH}$ to remove the aluminum-containing feed and then flushing with water to remove the $\mathrm{NaOH}$. The loading column was then isolated and a solution of $1 M$ formic acid was used to elute the cesium downflow through the column. The elution results (SRL \#1 through \#6) are shown in Figure 4.2. Approximately $99 \%$ of the cesium was eluted in less than $10 \mathrm{cv}$ of $1 \mathrm{M}$ formic acid, at flow rates that were varied from 0.5 to $2 \mathrm{cv} / \mathrm{h}$. 


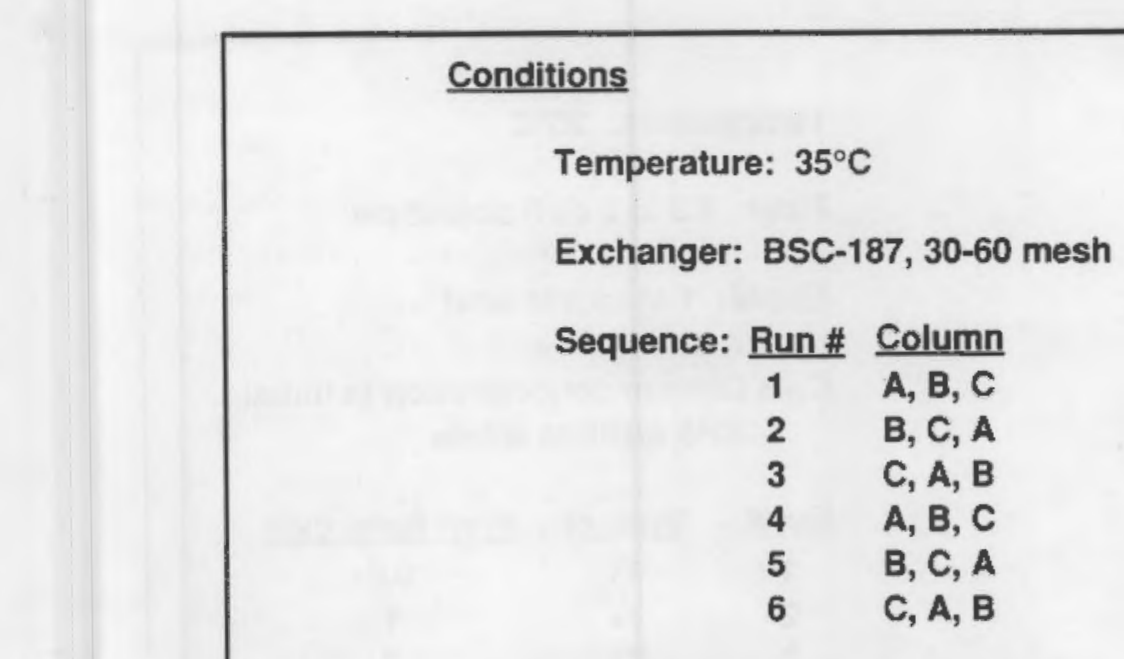

Columns: 1 in. dia. $\times 14.25$ in. $=200 \mathrm{~mL}$

Flow Rate: $\sim 2 \mathrm{cv} / \mathrm{h}$

Feed: Synthetic SRS Alkaline Supernatant,

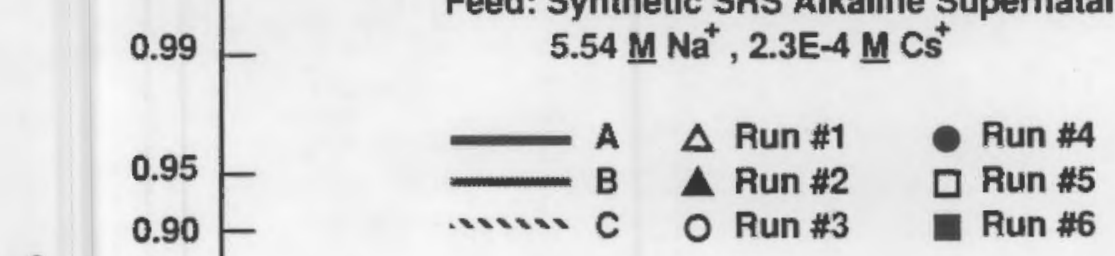

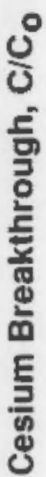

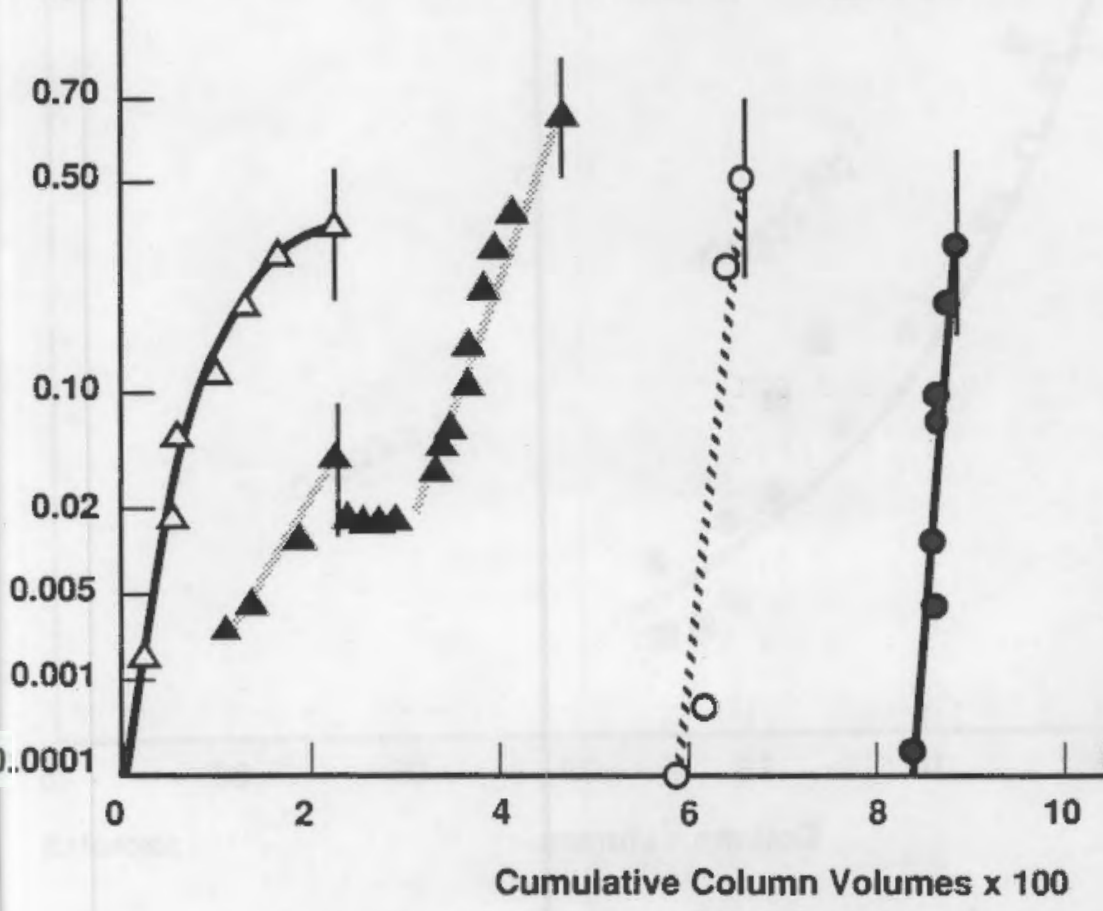

14

38908041.1

FIGURE 4.1. Cesium Breakthrough Profile for SRS Alkaline Waste Using BSC-187 Ion Exchange Resin 


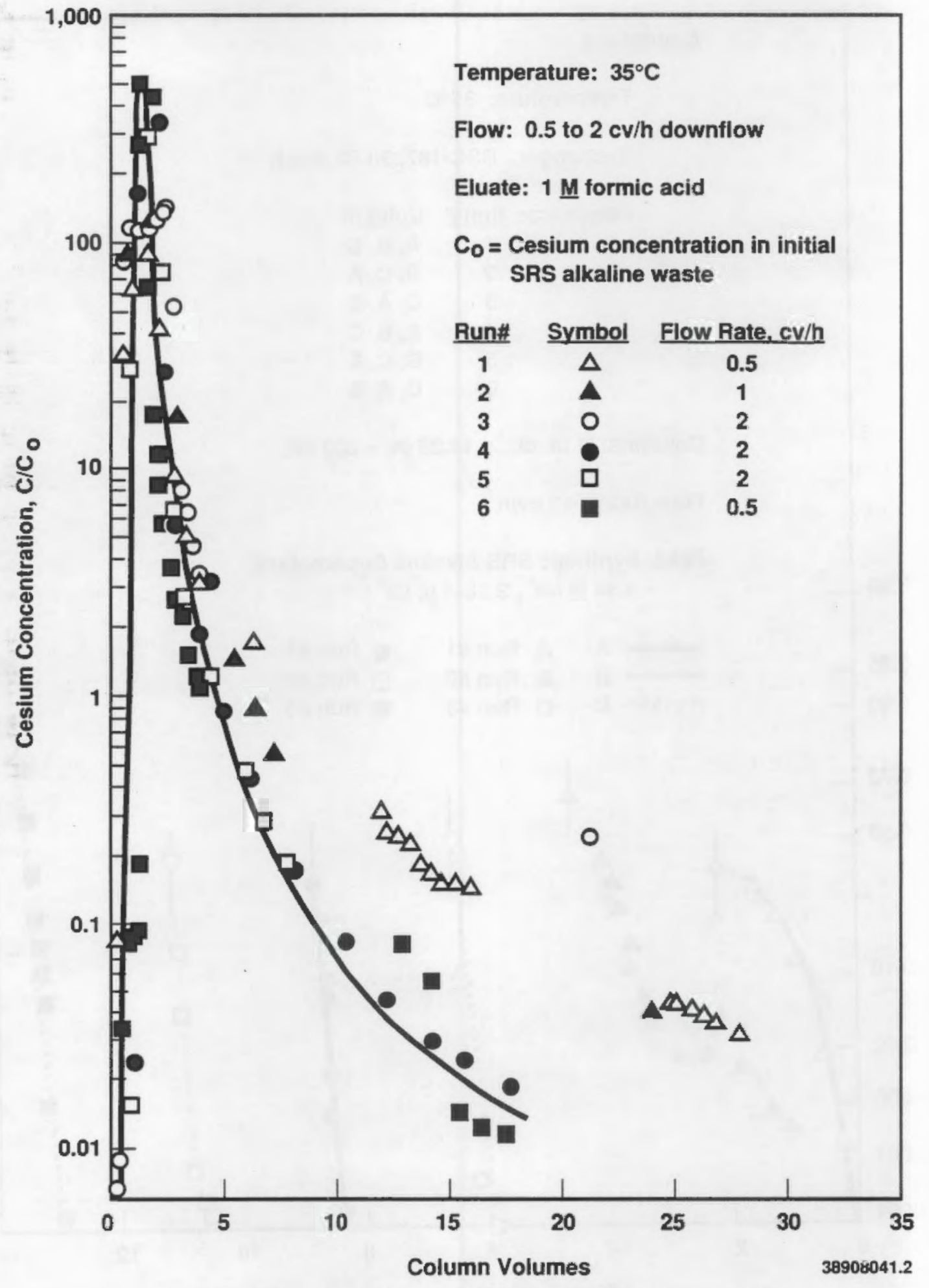

FIGURE 4.2. Cesium Elution Profile of BSC-187 Ion Exchange Resin Using Formic Acid 
An analysis of a sample of the feed and the formic acid product following test SRL \#11 is shown in Table 4.2. The results show that the DF for cesium from sodium was 1400 , and that the DF for cesium from potassium was 2400 .

\subsection{SINGLE-COLUMN CONF IGURATION}

The previously described carousel ion exchange tests did not shown a los 5 in cesium capacity after two loading/elution cycles for each of three columns. Therefore, five additional simplified tests were performed using only column $C$ with no trailing columns. The ion exchange resin continued to show excellent performance during the next five loading/elution cycles (SRL $\# 7$ through $\# 11$ ). The cesium loading capacity, based on column volumes of faed passed through the column until a cesium $C / C_{0}$ of 0.5 was obtained, variad, as follows: $195 \mathrm{cv}$ (SRL \#3), $239 \mathrm{cv}$ (SRL \#6), $233 \mathrm{cv}$ (SRL \#7), $203 \mathrm{zv}$ (SRL \#8), $188 \mathrm{cv}$ (SRL \#9), $190 \mathrm{cv}$ (SRL \#10), and $186 \mathrm{cv}$ (SRL \#11). Compared to the average value of $220 \mathrm{cv}$ for the carousel loadings, a loss in capacity of approximately $20 \%$ appears to be a reasonable estimate after completion of a total of seven loading/elution cycles. However, the loading on the last cycle with this bed was only $5 \%$ lower than the loading on the firs: cycle. The results are shown in Table 4.3.

TABLE 4.2. Decontamination Factors During Loading/Elution

SRL \#11 Feed: $\quad 121 \mathrm{~g} \mathrm{Na} / \mathrm{L}$

$$
\begin{aligned}
& 0.583 \mathrm{~g} \mathrm{~K} / \mathrm{L} \\
& 0.048 \mathrm{~g} \mathrm{Cs} / \mathrm{L}
\end{aligned}
$$

Formic Acid

Product:

$$
\begin{aligned}
& 0.61 \mathrm{~g} \mathrm{Na} / \mathrm{L} \\
& 0.0017 \mathrm{~g} \mathrm{~K} / \mathrm{L} \\
& 0.342 \mathrm{~g} \mathrm{Cs} / \mathrm{L}
\end{aligned}
$$

DF :

$\mathrm{Na}, 1,423$

$\mathrm{K}, 2,443$ 
IABLE 4.3. Cesium Breakthrough Values as a Function of Feed Volume, Phase 2--Single Column Configuration

\begin{tabular}{|c|c|c|c|c|c|c|c|c|c|}
\hline \multicolumn{2}{|c|}{$\begin{array}{r}\text { Run } \# 7 \\
\text { Column } C(3)(a) \\
\end{array}$} & \multicolumn{2}{|c|}{$\begin{array}{c}\text { Run } \# 8 \\
\text { Column } C(4) \\
\end{array}$} & \multicolumn{2}{|c|}{$\begin{array}{c}\text { Run } \# 9 \\
\text { Column } C(5) \\
\end{array}$} & \multicolumn{2}{|c|}{$\begin{array}{r}\text { Run } \# 10 \\
\text { Column } C(6) \\
\end{array}$} & \multicolumn{2}{|c|}{$\begin{array}{r}\text { Run } \# 11 \\
\text { Column } C(7) \\
\end{array}$} \\
\hline$\overline{c v}$ & $\mathrm{C} / \mathrm{C}_{0}$ & $\overline{c V}$ & $c / C_{0}$ & $\overline{c V}$ & $\mathrm{c} / \mathrm{C}_{0}$ & $\overline{c V}$ & $\mathrm{c} / \bar{C}_{0}$ & $\overline{c V}$ & $\mathrm{C} / \mathrm{C}_{0}$ \\
\hline 203 & 0.0001 & 107 & 0.07 & 175 & 0.165 & 170 & 0.07 & 171 & 0.20 \\
\hline 208 & 0.0014 & 143 & 0.04 & 188 & 0.50 & 190 & 0.50 & 174 & 0.25 \\
\hline 213 & 0.012 & 160 & 0.04 & 197 & 0.76 & 201 & 0.69 & 179 & 0.35 \\
\hline 223 & 0.19 & 197 & 0.32 & 199 & 0.81 & 208 & 0.78 & 183 & 0.42 \\
\hline 233 & 0.50 & 201 & 0.43 & 201 & 0.84 & 212 & 0.83 & 185 & 0.46 \\
\hline \multirow[t]{3}{*}{244} & 0.78 & 203 & 0.50 & 203 & 0.90 & 216 & 0.84 & 186 & 0.50 \\
\hline & & 205 & 0.58 & & & & & 199 & 0.71 \\
\hline & & 213 & 0.77 & & & & & & \\
\hline
\end{tabular}

(a) ( ) = number of times column has been used as the loading column.

\subsection{PHYSICAL PROPERTIES}

The CSRF ion exchange resin was pretreated with $2 \mathrm{M} \mathrm{NaOH}$ before being placed in a column ( $1 \mathrm{in}$. in diameter by $16.5 \mathrm{in}$. in length) having a $200-\mathrm{mL}$ capacity. The $72 \mathrm{~g}$ of exchanger gave a bed that was $14.25 \mathrm{in}$. in height. During subsequent loading, $\mathrm{NaOH}$ and $\mathrm{H}_{2} \mathrm{O}$ washing, formic acid elution, and $\mathrm{H}_{2} \mathrm{O}$ and $\mathrm{NaOH}$ pretreatment of the ion exchange resin, the organic resin expanded and contracted in bed height. The maximum expansion $(14.25+1.5 \mathrm{in.})$ occurred after the completion of loading followed by $\mathrm{NaOH}$ and $\mathrm{H}_{2} \mathrm{O}$ washing, and prior to formic acid elution. The maximum contraction (14.25 - 5 in.) of the bed occurred during formic acid elution. The expansion and contraction observations during the first nine tests are summarized in Table 4.4. In addition, it was observed that during formic acid elution, the resin contracts not only in length but away from the side walls of the jon exchange column. Channeling during formic acid elution was predicted based on the 
TABLE 4.4. Expansion and Contraction of Columns During Cycles

\begin{tabular}{|c|c|c|c|c|c|c|}
\hline Run \# & Sequence & $\begin{array}{l}\text { ge in Leng } \\
\text { Before } \\
\text { Loading }\end{array}$ & $\begin{array}{l}\text { of Ion } \\
\text { After } \\
\text { Loading }\end{array}$ & $\begin{array}{l}\text { change Col } \\
\text { After } \\
\mathrm{NaOH} \text { Wash }\end{array}$ & $\frac{n \text { in. (a) }}{\text { After }}$ & $\begin{array}{l}\text { After (c) } \\
\text { Elution }\end{array}$ \\
\hline 1 & $A, B, C$ & $--(d)$ & -- & - & -- & -- \\
\hline$?$ & $\begin{array}{l}\text { B } \\
\text { C } \\
A\end{array}$ & $\begin{array}{l}+1.25 \\
+2 \\
+1\end{array}$ & $\begin{array}{l}-- \\
-- \\
--\end{array}$ & $\begin{array}{l}-- \\
--\end{array}$ & $\begin{array}{l}-- \\
-- \\
--\end{array}$ & $\begin{array}{l}-- \\
+-\end{array}$ \\
\hline 3 & $\begin{array}{l}\mathrm{C} \\
\mathrm{A} \\
\mathrm{B}\end{array}$ & $\begin{array}{l}+1.75 \\
+1.5 \\
-1.25\end{array}$ & $\begin{array}{l}+0.75 \\
-1 \\
-1.25\end{array}$ & $\begin{array}{l}+0.75 \\
-0.5 \\
-1\end{array}$ & $\begin{array}{l}+1.38 \\
+1 \\
+1.5\end{array}$ & $\begin{array}{l}-- \\
+0.5 \\
--\end{array}$ \\
\hline 4 & $\begin{array}{l}\mathrm{A} \\
\mathrm{B} \\
\mathrm{C}\end{array}$ & $\begin{array}{l}+0.5 \\
+1 \\
-2\end{array}$ & $\begin{array}{l}-1 \\
-0.25 \\
-1.25\end{array}$ & $\begin{array}{l}-0.75 \\
0 \\
-1\end{array}$ & $\begin{array}{l}+0.13 \\
+1.5 \\
+1.38\end{array}$ & $\begin{array}{l}-5 \\
-- \\
--\end{array}$ \\
\hline 5 & $\begin{array}{l}B \\
C \\
A\end{array}$ & $\begin{array}{l}-- \\
-- \\
--\end{array}$ & $\begin{array}{l}-0.25 \\
0 \\
-0.5\end{array}$ & $\begin{array}{l}0 \\
0 \\
-0.25\end{array}$ & $\begin{array}{l}+1 \\
+1.5 \\
+1\end{array}$ & $\begin{array}{l}-4.5 \\
-- \\
--\end{array}$ \\
\hline$b$ & $\begin{array}{l}C \\
A \\
B\end{array}$ & $\begin{array}{l}+1 \\
+0.25 \\
-1.75\end{array}$ & $\begin{array}{l}-0.5 \\
-1 \\
--\end{array}$ & $\begin{array}{l}-0.5 \\
-0.5 \\
--\end{array}$ & $\begin{array}{l}+0.5 \\
+0.75 \\
-\end{array}$ & $\begin{array}{l}-5.25 \\
-- \\
--\end{array}$ \\
\hline 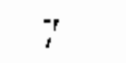 & C & +1.5 & -0.38 & -0.5 & +0.5 & -5.5 \\
\hline 8 & C & +0.75 & -1.25 & -0.5 & +0.75 & -4 \\
\hline 9 & C & +1 & -0.25 & 0 & +0.5 & -5 \\
\hline
\end{tabular}

(a) Expansion or contraction of resin assuming that $14.25 \mathrm{in},=200 \mathrm{~mL}$.

(b) After $\mathrm{H}_{2} \mathrm{O}$ and $2 \mathrm{M} \mathrm{NaOH}$ wash.

(c) Only first column in series was eluted with 1 늠 formic acid.

(d) -- signifies no data available.

physical contraction of the organic ion exchange resin but, as shown in Figure 4.2, was not observed in the cesium elution profile except for the first elution \#1. 


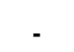

- 


\subsection{REFERENCES}

Bibler, J. P., and R. M. Wallace. 1987. Preparation and Properties of a Cesium Specific Resorcinol-Formaldehyde Ion Exchange Resin. DPST-87-647, Savannah River Laboratory, Aiken, South Carolina.

Bray, L. A., D. E. Kurath, W. A. Ross, and D. K. Ploetz (WVNS). 1989. Correlation of Laboratory Testing and Actual Operations for the West Valley Supernatant Treatment System. Presented at the Fourth International Symposium on Ceramics in Nuciear Waste Management, American Ceramic Society Annual Meeting, Apri1 23-27, 1989. PNL-SA-16871, Pacific Northwest Laboratory, Richland, Washington. 


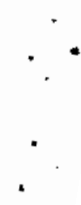


PNL -7273

UC -510

\section{DISTRIBUTION}

No. of

Copies

OFFSITE

12 DOE/Office of Scientific and

Technical Information

2 DOE Office of Civilian Radioactive Waste Management

Forrestal Building

Washington, DC 20585

ATTN: S. Rousso, RW-10

R. Stein, RW-30

2 DOE Office of Defense Waste \& GTN Transportation Management

Washington, DC 20545

ATTN: K. A. Chacey, DP-123

T. B. Hindman, DP-12

4 DOE Office of Waste Operations GTN

Washington, DC 20545

ATTN: J. E. 8aublitz, NE-20

J. A. Coleman, EM-35

T. W. McIntosh, EM-343

H. F. Walter, EM-343

A. T. Clark

Division of Fuel Material Safety

Nuclear Regulatory Commission

Washington, DC 20555

V. Stello

Office for the Executive Director for Operations

Mail Station 17-G21

Nuclear Regulatory Commission

Washington, DC 20555

S. Meyers

Environmental Protection Agency

Office of Radiation Programs (ANR-458)

401 M Street S.W.

Washington, DC 20460
No. of

Copies

P. A. Saxman

DOE Albuquerque Operations Office P.0. Box 5400

Albuquerque, NM 87185

E. Maestas

DOE West Valley Project

P.0. Box 191

West Valley, NY 14171

3 DOE Idaho Operations Office

785 DOE Place

Idaho Falls, ID 83402

ATTN: C. R. Enos

M. W. Shupe

J. E. Solecki

F. T. Fong

DOE San Francisco Operations

1333 Broadway

Dakland, CA 94612

M. R. Jugan

DOE Oak Ridge Operations office

P.0. Box E

Oak Ridge, TN 37830

W. T. Goldston

DOE Savannah River Operations office

P.0. Box A

Aiken, SC 29801

H. L. Brandt

DOE Savannah River Operations Office

P.0. Box A

Aiken, SC 29801

M. J. Steindier

Argonne National Laboratory

9700 South Cass Avenue

Argonne, IL 60439 
No. of

Copies

C. S. Abrams

Argonne National Laboratory

P.0. Box 2528

Idaho Falls, ID 83401

3 Battelle Memorial Institute Project Management Division 505 King Avenue

Columbus, $\mathrm{OH} 43201$

ATTN: W. A. Carbeiner

R. A. Nathan

Technical Library

L. D. Ramspott

Lawrence Livermore National Laboratory

University of California

P.0. Box 808

Livermore, CA 94550

D. T. Oakley, MS-J521

Los Alamos National Laboratory

P.0. Box 1663

Los Alamos, NM 87545

$4 \quad$ Oak Ridge National Laboratory

P.0. BoX Y

Oak Ridge, TN 37830

ATTN: W. D. Burch

R. T. Jubin

L. J. Mezga

D. W. Turner

2 Sandia Laboratories

P.0. Box 5800

Albuquerque, NM 87185

ATTN: R. W. Lynch

Technical Library

J. R. Berreth

Westinghouse Idaho Nuclear Co., Inc.

P.0. Box 4000

Idaho Falls, ID 83401
No. of

Copies

7 Westinghouse Savannah River Co. Savannah River Site

Aiken, SC 29801

ATTN: R. G. Baxter

J. P. Bibler 773A

M. D. Boersma 77341A

J. R. Knight $773 \mathrm{~A}$

M. J. Plodinec 773A

C. T. Randall 7042

R. M. Wallace $773 \mathrm{~A}$

A. D. Rodgers

EG\&G Idaho

P.0. Box 1625

Mail Stop 2411

Idaho Falls, ID 83415

R. Shaw

Electric Power Research

Institute

3412 Hillview Avenue

P.0. Box 10412

Palo Alto, CA 94303

4 West Valley Nuclear Services Co. P.0. Box 191

West Valley, NY 14171

ATTN: R. R. Borisch

J. Buggy

J. M. Pope

R. A. Thomas

J. L. White, Chairman

Energy Research \& Development Authority

Empire State Plaza

Albany, NY 12223

\section{ONSITE}

6 DOE Richland Operations Office

M. J. Furman, A6-80

R. E. Gerton, A6-80

E. C. Norman, A5-51

J. C. Peschong, A6-80

S. M. Prestwich, A6-80

G. W. Rosenwald, A6-80 
No. of

Copies

14 Westinghouse Hanford Company

J. N. Appe], R2-07

A. L. Boldt, R2-11

D. R. Bratze], T6-50

J. M. Henderson, G6-02

D. L. Herting, T6-50

T. L. Jones, S6-08

B. C. Landeene, R2-07

R. E. Lerch, B2-35

R. M. Orme, R2-07

A. L. Prignano, T6-50

J. L. Scott, R2-87

R. A. Smith, G6-02

D. D. Wodrich, Rl-48

B. A. Wolfe, L5-6]
No. of

Copies

32 Pacific Northwest Laboratory

C. R. ATlen, G6-01

W. F. Bonner, P7-44

L. A. Bray (10), P7-25

H. C. Burkholder, P7-4l

R. E. Einziger, $P 7-14$

H. D. Freeman, K2-12

L. K. Holton, Jr., P7-41

B. J. Kaiser, PB-01

D. E. Kurath, P7-41

D. E. Larson, G6-01

J. L. McEl roy, IP7-46

K. A. Parne11, P7-18

W. A. Ross, P7-41

S. C. Slate, K6-27

J. L. Swanson, P7-25

J. H. Westsik, P7-44

E. J. Wheelwright, P7-25

Publishing Coordination

Technical Report Files (5) 
3 